Article

\title{
Double Visions: Autobiography and the Ends of Philosophy
}

\section{Neil Gascoigne}

Department of Politics and International Relations, Royal Holloway, University of London, Egham, Surrey, TW20 0EX, UK; E-Mail: Neil.Gascoigne@rhul.ac.uk; Tel.: +44-1784-276451

Received: 23 May 2013; in revised form: 19 June 2013 / Accepted: 9 July 2013 /

Published: 10 July 2013

\begin{abstract}
In Contingency, irony and solidarity Rorty attempts to solve what Robert Pippin calls the 'Modernity Problem' by outlining a new self-understanding for the intellectuals of the ideal liberal society. The so-called liberal ironists of this post-philosophical milieu are no longer characterized by the quest for what Rorty describes as 'a single vision'. This paper evaluates Rorty's attempt to conceptualize the self-image of post-philosophical intellectuals in the light of two similar endeavors; namely, Nietzsche's and the ancient Sceptics'. The preliminary conclusion is that although Rorty's attempt fails, it points to an alternative way of interpreting the desire for a single vision; namely, as a form of autobiography. Drawing on Nietzsche, Nagel and Mill, the paper proceeds to argue that Rorty's own autobiographical fragment exemplifies the way in which the narration of a failed attempt to find a 'single vision' can itself be seen as the achievement of such a vision.
\end{abstract}

Keywords: liberal ironist; autobiography; ancient scepticism; Nietzsche; modernity problem; intellectual self-understanding; Mill; Nagel

\section{No Single Vision}

In a recent essay on Isaiah Berlin, Mark Lilla notes that the works of "important thinkers... seem to be held together by some centripetal psychological force, even if the author changed his mind about important matters". He goes on to note that thirty years ago an unnamed classicist had in conversation remarked of an unnamed "American philosopher who had recently become famous for writing a blockbuster announcing that philosophy... is just a kind of literature” that " He's hated philosophy since he was eighteen"”. The anonymous philosopher, Lilla implies, numbered amongst those who lack the self-awareness to distinguish "the quest for truth" from the desire for "comfort or recognition or revenge or support for their moral and political prejudices” ([1], p. 41). 
It requires no great perspicacity to identify Rorty as Lilla's target here; though the 'psychological force' putatively at play in the constitution of his intellectual life is curiously understated. After all, one might have hated French since primary school without one's disinclination in any way serving to characterise one's intellectual trajectory. If the invoked emotion is to convey any insight in this context it's evidently because philosophy, unlike French, is something that one can hate without knowing it; that one's hatred can be so concealed from oneself that it twists and distorts one's relationship to the discipline one continues nevertheless to practice; that the self-deception is such as to cause one to present under its sway an account purporting to be of universal applicability.

If something in this characterisation chimes even with those more sympathique to Rorty than Lilla, it is not because the former was straightforwardly unaware of his relationship to the discipline. In Contingency, irony, and solidarity Rorty identifies the dream-quest of philosophy as the "attempt to hold all sides of our life in a single vision, to describe them with a single vocabulary” ([2], p. xvi). But if Plato saw his utopia as a state in which intellectuals realise their destiny as philosopher-kings, Rorty's ideal liberal society is one wherein the attempt "to fuse the public and the private" ([2], p. xiii) has been abandoned. Or rather, it is from our perspective that such an aspiration has been forsaken. From the standpoint of the future intellectuals such an undertaking plays no part in their self-understanding. It no more figures as a live possibility for them than the life of a medieval stylite does for us.

A heightened sense of awareness doesn't render one immune to self-deception, however. Perhaps only those disinterested in or ignorant of something — be it French or philosophy-escape fully the 'logic' of opposition. It is in respect of that relation between where 'we' are and the self-understanding of the future intellectual that the more receptive reader of Rorty might find a source for the selfdeception that Lilla hints at so crudely. For the attempt to delineate his utopia, and with that a sense of the appeal it might have for 'we' intellectuals, comes to provide the context for the answer to what Rorty describes as longstanding "worries about what, if anything, philosophy is good for” ([3], p. 11). On this account philosophy finds its 'end' by helping bring to a close the very conception of the intellectual quest that invested it with its identity.

This exhibits something of the formal aspect of the problem of 'ending' philosophy, but it hints too at the existential dimension that Lilla strains to exploit. By ending the philosophical quest one brings to an end the conception of the intellectual's self-understanding that derived from their privileged relation to that quest. And the insinuation that the self-understanding one has achieved through one's own escape from philosophy (and the false self-image it provides) can gesture towards (or serve as) a model for post-philosophical thinking in general is a promising place to look for the sort of inconsistencies that might tip one off to a thinker's thought being 'controlled' by, in some more subtle way than hatred for, the very thing they seek to avoid.

In Section 2 I'll evaluate Rorty's response to this so-called 'reflexive' problem alongside two paradigms of the attempt to end philosophy. In doing so the aim is to address, in a Rortian spirit, the more general question of where the rejection of the idea of a philosophical quest for a single vision leaves the intellectual. What manner of self-understanding can she aspire to if there is to be no theoretical reconciliation of private and public, no standpoint from which the values articulated in the languages of "self-creation and justice, private perfection and human solidarity" ([1], p. xiv) can be combined into the same idiom? If it is from the standpoint of (say) the 'transcendental subject' that the theoretical quest is undertaken, from what standpoint might one do justice to the desire for a single 
vision by allowing for the integration of idiosyncratic interests and commitments to others? Taking up Rorty's suggestion that the rejection of the idea of a single vision is emblematised in "a general turn against theory and toward narrative” ([2], p. xvi); that 'philosophy... is just a kind of literature'; the best one can make of this 'standpoint' talk is in terms of genre. The question, then, is what form of story could articulate the standpoint from which to link up private and public concerns in the fashioning of a self-narrative? In Section 3 I shall suggest that the genre embracing the autobiographies of philosophers can serve as a paradigm in the attempt to understand such a standpoint ${ }^{1}$. In the concluding section this will relate back to Lilla's piece in a perhaps unexpected way.

\section{Irony between Scepticism and Ressentiment}

In this section we'll examine two approaches to 'ending' or transforming philosophy: Nietzsche's and the ancient Sceptic's ${ }^{2}$. The concern is not specifically with the question of direct influence, though there are references aplenty to Nietzsche in Rorty's work and his awareness of the relevance of this tradition of sceptical reasoning for contemporary metaphilosophy is evident as early as his introduction to $[7]^{3}$. Rather, they are useful for locating Rorty's own approach in the light of the two aspects of the 'reflexive' problem noted above: the formal issue of using philosophy to end philosophy and the existential issue of the individual's own relation to that process of 'ending'.

In Beyond Good and Evil, Nietzsche makes a distinction between, on the one hand, "philosophical labourers, and scientific men in general,” and, on the other, "the genuine philosopher” ([10], §211). In The Will to Power, he is particularly expansive concerning the work of the former:

The history of philosophy is a secret raging against the preconditions of life, against the value feelings of life, against partisanship in favour of life. Philosophers have never hesitated to affirm a world provided it contradicted this world and furnished them with a pretext for speaking ill of this world. It has been hitherto the grand school of slander ([11], §461).

This 'secret raging' is expressed in what Nietzsche calls the desire "to overcome the entire past"; an inauthentic compulsion to summarise its values, to encapsulate them, package them as unyielding truths and thereby possess them. In contrast, the genuine philosophers reach out for the future: they are, he continues, “commanders and legislators: they say, 'That is how it should be!’” ([10], §211). Despite the distinction, however, the genuine philosopher stands in a problematic relation to the tradition: "It seems increasingly clear to me," he writes, "that the philosopher, being necessarily a person of tomorrow and the day after tomorrow, has, in every age, been and has needed to be at odds with his today: his enemy has ever always been the ideal of today” ([10], §212).

Since the philosopher is, as Nietzsche suggests, of necessity antagonistic towards a certain way of being or of living, he must as a consequence experience the tedium of philosophical labour himself. Or, rather, it is in virtue of that labour that he finds himself experiencing that antagonism, a state of restless being that can be relieved only through the creation of new values. But the value-space of that

1 The notion of an autobiographical standpoint or self is deployed across literary studies [4] and psychology [5], and I attempt no definition of it here.

2 There were of course rival schools of Scepticism in the ancient world. See for example ([6], ch. 2).

3 See ([8], pp. 109-23) for details. For early reflections on parallels between Rorty and the ancient Sceptics see [9]. 
tomorrow is not thinkable from the perspective of the philosophical labourer; so whilst the necessary condition of being a genuine philosopher is initiation into that way of being or of living, the latter cannot itself be vouchsafed a role in providing values for that future. Indeed, the only content that Nietzsche can seem to give to the 'end' of such a philosophy is when he writes that "Not 'mankind' but overman is the goal!' ([11], §1001) and that “The word 'overman' is the designation of a supreme achievement” ([12], p. 717). The concept of the overman, however, bears the same problematic relationship to the concept of man as that of the genuine philosopher does to that of the philosophical labourer: in each a necessary relation to the other must be assumed in order to assert its utter distinctness from it.

We are left, then, with two familiar and inter-dependent questions:

I. What is the relationship between the 'future philosophy' and the tradition such that it can be seen as both a continuation of it and a radical break from it?

II. How can one justify a break with the tradition, when the only values available to conceive of an alternative are provided by the tradition itself, and thus risk infecting that new conception from the very outset. How, in other words, could one discern an end in the 'secret raging against life' that was not itself part of that rage?

The perceived failure of Nietzsche to provide a satisfactory response to (I) and (II) engenders the suspicion that his thinking is 'controlled' by the fear that his philosopher's 'contradiction to his today' is merely a reflection of his own ressentiment: his sense that he too was doomed to overcome inauthentically the past, and would never become more than the sum of all the values his 'higher men' had provided him with (cf. [13]). Habermas touches on this existential aspect of the reflexive problem when he claims that "with Nietzsche the criticism of modernity dispenses for the first time with its retention of an emancipatory content” ([14], p. 94). For Habermas, Nietzsche's thought marks the juncture at which 'the philosophy of subjectivity' collapses to a point where a purified subjectivitypure Will-is purged of the values of modernity and has to create new values ex nihil. No emancipatory content remains, because "the morality of communal pity" ([10], §202) informs the political and social institutions of liberalism, and that is the morality of the despised herd. But for Nietzsche the 'critique of modernity' is rather an unmasking of its self-deceiving failings to acknowledge the real depth of the 'emancipatory project' when confronted with the absence of traditional modes of exculpation. In this sense it characterizes what Pippin calls the 'Modernity Problem': the "problem of 'autonomy,' or of genuine self-determination or self-rule” that derives from doubts about modernity's promise to "deliver... an individually and collectively self-determining life" ([15], p. 3). It is the problem to which Contingency, irony and solidarity seeks a solution ${ }^{4}$. Before looking at Rorty's response to it, let's consider briefly his earlier reflections on the reflexive problem, written at a time when he still appears to have had more faith in what philosophy 'is good for'.

In Consequences of Pragmatism, Rorty contrasts 'Philosophy' with a big 'P', with 'philosophy' with a small ' $p$ '. Philosophy, he writes, is "a genre founded by Plato... the... history of attempts to... find something interesting to say about the essence of Truth... and... of criticisms of those attempts” ([17], p. xiv). Opposed to this is 'philosophy'; in the oft-quoted Sellarsian saw, "the attempt to see how

4 For more on the relation to Pippin see [16]. 
things, in the broadest possible sense of the term, hang together in the broadest possible sense of the term" 5 . Philosophy is an autonomous discipline, or Fach, in that it gives one "distinctions to use in setting it off from those... other realms of discourse... alongside, or below it” ([17], p. 22). In the other sense it has no such legislative framework, and consequently "Blake is as much a philosopher as Fichte, Henry Adams more of a philosopher than Frege” ([17], p. xv).

In describing philosophy as opposed to Philosophy one raises a moot point. To confront Philosophy — to be recognised as doing Philosophy by a Philosopher-is to adopt the distinctions constitutive of the Fach, and thereby be condemned to perpetuate it. For Rorty, then, the problem facing the pragmatist is to "find ways of making antiPhilosophical points in nonPhilosophical language” ([17], p. xiv). But then it becomes clear that the pragmatist is not the philosopher, who inhabits a "post-Philosophical culture" ([17], p. xl), for that is decidedly not the culture we occupy: if it were there would be no task for the pragmatist. Although Rorty does not make the point explicit, then, the pragmatist is the one who mostly gestures towards such a culture whilst still participating in the discourse of Philosophy. Only on that basis might one claim that, for example, assenting to Nelson Goodman's view that we make worlds rather than find them, or that taking "the ubiquity of language... seriously” ([17], p. xxxix) will lead anywhere. That cannot be constitutive of the philosopher's view because she has no such view, serious or otherwise. Only if the Philosopher takes it seriously might it make possible a movement towards that culture.

If it is the case that a post-Philosophical culture is desirable; if it could be conceived of as being "better" ([17], p. xxxviii); our conception of it must already be immanent in contemporary culture. That suggests that the roots of that possible culture lie in the present one, which to some degree must therefore be philosophical; and that in turn suggests that the Philosophy that pragmatism opposes is a dogmatic, limiting accretion: something that gets in the way of realising that culture. In a piece originating from a review of Crispin Wright's Truth and Objectivity, we find a statement of the pragmatist's task that chimes with this conclusion. Pragmatists, he concludes,

should see themselves as working at the interface of their community, a common sense much influenced by Greek metaphysics and by monotheism, and the startlingly counterintuitive self-image sketched by Darwin, and partially filled in by Dewey. They should see themselves as involved in a long-term attempt to change the rhetoric, the common sense, and self-image of their community ([18], p. 41).

For Rorty, like Nietzsche (and Heidegger and Dewey), it is the sanctification of Greek metaphysics by Western monotheism, enshrined in common-sense, that is suffocating culture. Crucially, where for Nietzsche the failure to envisage a future philosophy arising from the tedium of 'Philosophical labour' collapses into ressentiment, Rorty comes to drop all talk of philosophy's role in a post-Philosophical culture $^{6}$. Referring to (I), then, the future culture is continuous with the present insofar as it embraces the Enlightenment values characteristic of 'the morality of communal pity'; it is a break with the present insofar as those values, assumed by the philosophical tradition to require or possess a rational foundation, are released from that particular tutelage. Respecting (II), embracing these values - this legacy of modernity - warrants the rejection of the tradition from which they spring on the basis that

Quoted on ([17], p. xiv). Cf. ([17], p. 29).

6 See ([8], pp. 107-41) for a detailed account of Rorty’s attempt to ‘overcome’ Philosophy. 
the very idea of a rational ground renders then vulnerable to nihilistic rage. It thus becomes central to that 'change' in rhetoric to redescribe whomever an audience takes to be a major thinker as articulating some version of pragmatism ${ }^{7}$, and so Nietzsche takes his places alongside Heidegger and Davidson (and Goodman) in the newly refurbished pragmatist pantheon ${ }^{8}$.

As it stands, this raises two related questions: why embrace these values and how avoid the charge that they are anti-life (a contention which itself presages ressentiment)? But to whom are these questions addressed? The first thing to bear in mind here is that when Rorty talks of the 'community' he is not referring to the company of equals. 'Our' community, like the majority of folk in the ideal liberal society, consists mostly of nonintellectuals. So the foot soldier of the pragmatist new model army does not simply share that commonsense self-image: hers is the self-understanding of the convert or visionary who has glimpsed, through the cave entrance, the sunlit uplands beyond; who is selfconsciously engaged in getting others to think about themselves in a different way in order to help bring about the liberal utopia. If the cave is the 'single vision', Rorty's version of Nietzsche's 'secret raging against the value feelings of life', in near-escaping it one is not led to a truth, the whole content (Philosophically) of which is to be communicated to others. They don't need to become pragmatists, but need merely to possess a self-understanding more reflective of post-Philosophical commonsense and more likely to conduce to the entrenchment of the values of modernity they already accept.

Inquiring why these values should be embraced, and how they are to be viewed in relation to Nietzsche's challenge, then, we are restating the 'Modernity Problem' as it's presented to intellectuals (whom else?). Contingency, irony and solidarity proposes that a solution to it takes the form of an attempt to deploy resources from within Philosophy to put pressure on the idea that it, in the form of a quest for a single vision, can provide a self-image or account of self-understanding that is appropriate for the intellectual heir to modernity. In so doing it provides an alternative vision for the (future) intellectual's self-understanding. We can get some sense of how this might proceed by returning to the roots of the opposition to Philosophy. What Rorty omits in his characterisation of the Platonic genre is that it was driven by the idea that the quest for truth was the essential precursor to living a good life; that such a quest provided the self-image or account of self-understanding appropriate for the intellectual. And the earliest examples of how that self-understanding is sublimated under pressure on the intelligibility of such a quest are almost as old as Philosophy itself. Turning then to the second approach to 'escaping' Philosophy, the opening sections of the Outlines of Scepticism provide an appropriate starting point:

When people are investigating any subject, the likely result is either a discovery, or a denial of discovery and a confession of inapprehensibility, or else a continuation of the investigation. This, no doubt, is why in the case of philosophical investigations, too, some have said that they have discovered the truth, some have asserted that it cannot be apprehended, and others are still investigating.

For Sextus, these descriptions designate the "the most fundamental kinds of philosophy":

- The Dogmatists, who "think that they have discovered the truth".

- The Academics, who "have asserted that things cannot be apprehended".

7 Or at the very least not arguing for some version of transcendental philosophy. See for example [19].

8 The existential residue is relegated to the 'private'. 
- The Sceptics, “who are still investigating” ([20], p. 3).

These positions can be characterised as follows:

i. $D$ knows that we can know things

ii. A knows that we cannot know things

iii. $S$ doesn't know if we can know things or not

At the heart of Greek philosophy is the concern with living a good, virtuous or tranquil-that is to say, happy-life. For the Dogmatist the guiding idea is that it is through an account of the way things are in their essential nature, and what as a consequence we can know, that we are led to an understanding of how to achieve this. Since Sceptics of all varieties share Dogmatism's practical orientation, their aim in attacking it is not to undermine the conviction that there is an ideal sort of life for a human to live; rather, they use philosophy to undermine the assumption that the good life is to be characterized and attained through the acquisition of knowledge. Central to this is a sustained attack on the Dogmatist's idea that one can identify criteria of truth. The problems are traditionally (see [21]) thought to arise when one throws into the pot the basic precept of Scepticism:

iv. $S$ suspends judgement about/withholds assent from everything (non-evident)

Although this runs counter to the practical orientation of Greek philosophy in general, the Sceptic does have a response:

v. S goes along with appearances (the evident)

The concern is that (iv) appears to require assent and therefore rational ground. So either (iv) is justified by (ii), which seems self-refuting, or (iv) is ungrounded in which case it's not clear what would motivate someone to practice it. The key to the Sceptic's response is that they deploy dialectically the resources of Dogmatic philosophy to undermine the idea that the latter, through its privileged relation to the criterion (the 'touchstone') of truth, could determine how the intellectual (the Sage trained to assent only to what is true) should live the tranquil life (free from error). For Sextus Empiricus, the (at best) elusiveness of the criterion of truth indicates that the responsible intellectual should free herself from the seductive search for the Real by suspending judgement about competing claims to truth and going along with appearances. However, the full response to the issue of motivation only emerges when one appreciates that the Sceptic used to be a Dogmatist. The Sceptic thus conceives of her journey as follows: Seeking tranquility, the intellectual leaves behind the standards of action that are apparent to her (those found in common life) and begins a philosophical investigation in order to discover the knowledge that she believes will lead her to it. Encountering dissent everywhere she comes to see that in the realm of philosophical reasoning all speculation is on a par with respect to convincingness. Given this equivalence, the suspension of judgement is natural: if no one theory is any more convincing than another it would be arbitrary to assent to any. Fortuitously, the enquirer discovers that this withholding of assent actually issues in the sort of tranquility that she'd originally been seeking. When she returns to common life she finds that it provides all the motivation required for action. Moreover, if any investigation of the legitimacy of these appearances is suggested in the future (by herself or some other) by the invocation of a new standard, she re-enters the realm of 
philosophical debate and counterposes it with an equally reasonable or convincing alternative. Tranquility is restored.

The first thing to note is that because her relationship to the genre is as an outsider, the Sceptic cannot be judged to be advancing a Philosophically inconsistent position. She is making antiPhilosophical points in a nonPhilosophical language not because the words she uses are nonPhilosphical but because her use of them is. As an insider turned outsider, what she acquires through her training in resisting the blandishments of Dogmatic Philosophy is not an item of theoretical knowledge but a dialectical ability to contrast any argument that an interlocutor puts forward with another that is equally convincing; specifically, an ability that issues (contingently as it were) in tranquility. One might even conjecture that having made the accidental discovery herself that tranquility issues from Scepticism she might consider that her Dogmatist opponents-altered by their encounters with the Sceptic, and still animated by the desire to discover the good life-will eventually come to follow her path. Although not self-refuting, however, a certain degree of restiveness attends being a Sceptic. Formally at least this is because Sextus cannot consistently rule out a priori that someone will come up with a criterion that eludes the Sceptic's dialectical ability (since she is 'still investigating'). However, there's an existential dimension to this: although accidental, the Sceptic's tranquility is an achievement and is safeguarded only through her acquired dialectical prowess. The Sceptic continues to need the Dogmatist to hone that ability and assure that state of tranquility. Ever alert to the possible disruption to tranquility caused by herself or some putative Sage, then, Scepticism is essentially reactive. The second thing to note is that one cannot be a nonintellectual Sceptic. Someone might be deaf to the Siren-song of Philosophy and go along with appearances not because of his special training but because he is essentially uncritical or incurious. Since Hellenistic common sense, though absent the influence of Judeo-Christianity, was presumably no less Philosophical than our own, the non-Sceptic is ever-vulnerable to the possibility that he might, if he fell into the wrong company, develop an unsettling interest in truth. Moreover, the nonintellectual, non-Sceptic could not insulate themselves from the possibility or fear of error and could not as a consequence live a good life.

We'll consider the implications of this in due course, but for the time-being lets restrict our interest to the self-image or self-understanding of the intellectual and return to Nietzsche. As noted, respecting Nietzschean antagonism towards the values of modernity enshrined in the Philosophical tradition drain the post-Philosophical future of presently conceivable emancipatory content. Ancient Scepticism poses a similar problem, insofar as the exclusion of truth-talk threatens an etiolation of the domain of public reason. Their 'solution' to this is to go 'along with appearances', where these are taken to include "guidance by nature, necessitation by feelings, handing down of laws and customs” ([20], p. 9). These cannot be challenged from 'inside' the relevant practices, but only by assuming the sort of critical standpoint that is vulnerable to the Sceptic's attack on the criterion of truth. And it is in this sense that Rorty's brand of neo-pragmatism can be regarded as a modern variation on ancient Scepticism, since it ensures that the content of this societal 'given' is shaped in conformity to what Rorty describes as "pretty much the last word... in Western social and political thought”; namely, "Mill’s suggestion that governments devote themselves to optimizing the balance between leaving people's lives alone and preventing suffering” ([2], p. 63). In going along with this 'custom'; which is to say, going along with the values enshrined in the liberal democratic tradition and its institutions; one acknowledges that whilst it cannot be non-circularly justified (through, say, a philosophy of inter-subjectivity) it equally 
cannot be supplanted by something claiming to be true (in the name of Dogmatic Philosophy). Indeed, it is on the basis of what Rawl's would call their place in "our deeper understanding of ourselves and our aspirations" ([22], p. 519) that we can envisage their central role in the post-Philosophical society ${ }^{9}$.

This is the answer to the question 'why these values?'. Moreover, they cannot be convicted of an inauthentic rage against life because such a contention would similarly require a standpoint outside the intramundane. But that further question about values isn't addressed fully through this response because it doesn't deal with the aspect of the 'Modernity Problem' that bears on the individual's ('we' autonomous, self-determining products of modernity) —and in particular, the intellectual'sself-determination. It is in relation to this that a second Nietzschean theme was introduced; namely, the existential aspect of the reflexive problem. By making the question of authenticity central to philosophy, Nietzsche ran the risk of reducing his own contribution to an expression of ressentimentmere subjectivity-as-pure-will. For Habermas, the disdain for the philosophy of subjectivity relates to his view that purged of any potential for increasing what Rorty calls solidarity with others, it must be abandoned; which is to say, that Habermas identifies the desire for authenticity with the philosophy of subjectivity's failure to justify solidarity_authenticity and solidarity are thus mutually opposed. But in discovering the values of Mill's "sacred texts" [23] in common life space is similarly assured for the individual in which to determine what meanings to give to their life. Since (on the parallel with ancient Scepticism) these have never having been candidates for the universal values of the modern dogmatists ("good, bad and indifferent things" ([20], p. 205)), they are as such insulated from any sceptical assault ${ }^{10}$. The 'overwoman' performs her 'supreme achievement' in the domain of the private.

On the basis of the foregoing it appears that the role of the Dogmatist is played by the Philosopher in search of a 'single vision'; the successor to the Sceptic the liberal ironist who combines a commitment to the "ungroundable... hope that suffering will be diminished" with "radical and continuing doubts" about "the words in which we tell... the story of our lives" ([2], pp. xv, 73). Accordingly, the Sceptic's restless reactiveness towards philosophy and Nietzsche's ressentiment are transformed into the future intellectual's irony. And the reason for pressing such a parallel would be to demonstrate how Rorty avoids the problem of overcoming philosophy in characterising the self-image of the post-Philosophical intellectual and as a consequence escapes Lilla's suggestion that his thinking is in someway controlled by it. If that were the ambition, however, there are two problems. Firstly, if the liberal ironist is to play the role of the Sceptic they must each embark on a journey of maturation that finds them seeking and ultimately possessed of the ability to resist individually the desire to theorise (in a single vision) their will to create values and live a life that expresses public commitments. Perhaps, like the Sceptic, they'll feel obliged to share their discovery with other dogmatists in the hope that they too will undergo the conversion to the good life it brings. But this understanding of the liberal ironist's position is, like that of the Sceptic, caught up in the logic of its relationship to Philosophy. As an inquirer she must stand ready to test herself against and oppose any

9 This thought invites the suggestion that neo-pragmatism might be thought of as a variety not of Pyrrhonian but of Academic Scepticism. For possible links between the latter and a Humean-Wittgensteinian naturalism that might include Rorty see [6].

10 The does not denigrate them to the level of 'mere' aesthetic choices of course, because the contrast that implies is sustained by dogmatic Philosophy. See [24] for Rorty’s clearest (though most problematic) statement of this. 
new Philosophical view that might be advanced. The second problem is more quickly stated: the liberal ironists of Rorty's ideal liberal state have undergone no such conversion and the 'combination' of (public and private) values they live indicates nothing of the struggle and consequent ability that would be possessed by a dogmatist-turned-liberal ironist.

If the liberal ironist doesn't play the role of the Sceptic, what of the pragmatist? On the one hand the (Rortian) pragmatist has the task of chipping away at the "irredeemably Cartesian" [25] self-image of our community. To return to Platonic imagery, the pragmatist has returned to the cave with something to share; something that (like the Sceptic's dialectical ability) will inoculate its citizenry against the malediction that is Philosophy. They bear the gift of nominalism and historicism. But the pragmatist is also the theorist, who shows that the liberal ironist is a possible figure by revealing that the ressentiment underpinning Philosophy's will to truth (captured in the desire for a single vision) can be redescribed as irony. Indeed, Rorty acknowledges that "Irony is, if not intrinsically resentful, at least reactive” ([2], p. 88). Now, it is odd to characterize the ironist's attitude towards her 'final vocabulary' as one of 'radical and continuing doubt' if it is resentful or reactive; and that oddness is highlighted when Rorty continues to equate such doubt with being in a state of alienation. Alienation evokes some existential twist on the Sceptic's reactiveness or restiveness, rather than the sort of quasi-epistemic state suggested by 'doubt'. It suggests that what the pragmatist discovers in their anti-Philosophical quest is not just the liberal values of common life but something essential about what it is to be an intellectual. But it's hard to see why, if it's a defining feature of intellectuals, it isn't to some degree a feature of all of us: something akin to the metaphysics of the Will to Power ${ }^{11}$. With this in mind let's return to the nonintellectuals. Here we hit on an apparent contradiction. We are told, for example, that in the liberal utopia “ironism... is universal” ([2], p. xv) and that its citizens “would be liberal ironists' ([2], p. 61). Moreover, embracing the contingency of language (and, by extension, of self and of community) is held equivalent both to being 'nominalist and historicist' and to being an ironist. However, Rorty later contends that

In the ideal liberal society, the intellectuals would still be ironists, although the nonintellectuals would not. The latter would, however, be commonsensically nominalist and historicist ([2], p. 87).

As we've seen, the nonintellectual (non-Sceptic) cannot secure the good life. But for Rorty the majority of the citizens are nonintellectuals, and cannot as such be condemned to dissatisfaction. The respect in which they differ from the citizenry of today is simply that their self-image is commonsensically 'historicist and nominalist' as opposed to being “irredeemably Cartesian” [25]. Commonsense historicism and nominalism are no more reactive and resentful than commonplace metaphysics and monotheism are. But when such views are held Philosophically (as the pragmatist holds them) they are reactive in the way that the Sceptic's relationship to Dogmatism is. So the equivocation on the scope of 'irony' seems to be related to the extent to which common folk can indeed be said to share the 'defining feature of intellectuals'. The problem, then, is that while at times talk of irony invokes the condition of 'we' questing intellectuals, it also aims to take in our shared (existential) predicament. In such contexts (commonsense) historicism and nominalism are inflated to incorporate it. Unsurprisingly, this ambiguity also infects Rorty’s talk of the public-private distinction.

11 Or the 'metaphysics of the unconscious' since at this point in Rorty's narrative Freud is brought on stage. 
Formally, this relates to a split internal to the self-image of the value-creating, resentful ironist who is also a liberal. When irony is expanded to include everyone, however, it becomes suggestive of a division that would be of broader political interest; and as the debate around it attests to, Rorty's use of this distinction in such a context is unstable.

For Rorty, then, the conception of the post-Philosophical culture towards which the pragmatist gestures is shaped around an account of what the intellectual's self-understanding would be like. In this respect it is one more expression of the elitist sensibility one finds in Philosophy from Plato to Mill and onwards. But there is a further issue here. In opposing the quest for a single vision Rorty theorises its evasion. In so doing he abandons the relaxed 'inside' standpoint of the general 'we' and adopts instead an 'outside' view, aiming to give a narrative of intellectual life that might serve as a model for all. But that model is itself determined by the reactive relationship pragmatism necessarily has to Philosophy. The question this raises is why one would think that there is a 'single vision' of the self-understanding of future intellectuals? Why regard irony as the predicament of the intellectual rather than as a certain sort of intellectual's predicament, one 'controlled' by ongoing concern to achieve an 'outside' standpoint? The answer is that Contingency is an apologia for the resentful, self-absorbed quest of a particular individual. The journey of maturation that the Sceptic undergoes is indeed the model for the liberal ironist because the liberal ironist is Rorty. The category of future liberal ironists is as empty as that of the overman, a projection onto the future of an impossible escape from (in Rorty's sense) alienation. If this is the sense in which Rorty's project for outlining the future intellectual's self-understanding is a failure, it also indicates another sense in which it is a success. In the next two sections I will pursue this thought.

\section{Philosophy and Autobiography}

In the introduction I indicated that this paper was motivated by a general question about where the rejection of a Philosophical quest for a single vision leaves the intellectual. I went on to suggest that one could, from within Rorty's 'narrativist' framework, think about the quest for a single vision in non-Philosophical terms by considering what I called the 'autobiographical standpoint'. I concluded somewhat obscurely that this could be understood by thinking about the work of philosophy as in some sense autobiographical. In the preceding section I aimed to show how Rorty's own attempt to 'end' Philosophy and find an alternative self-understanding for the intellectual is most coherently understood in these terms. Now, this discussion was motivated by the charge made against Rorty by Lilla to the effect that Rorty's ‘ending' of Philosophy by redescribing it as 'just a kind of literature' was in some sense self-deceiving. The sentiment guiding Lilla's suspicion here-similarly unacknowledged—is one that is relevant both to Rorty's attempt to respond to the 'Modernity Problem' and to the invocation I have made of the relationship between Philosophy and autobiography. It is of course Nietzschean:

I have gradually come to realize what every great philosophy so far has been: a confession of faith on the part of its author, and a type of involuntary and unself-conscious memoir; in short, that the moral (or immoral) intentions in every philosophy constitute the true living seed from which the whole plant has always grown... there is absolutely nothing impersonal about the philosopher; and in particular his morals bear decided and decisive witness to who he is ([10], §6). 
For Nietzsche, the philosopher embarked upon the search for truth is a certain sort of biographer; one who aims to escape the contingencies that are constitutive of her finitude by appealing to a metaphysical realm that lies beyond. Now, insofar as the metaphor of biography holds good what is under consideration here is a form not of auto- but of self-biography. To appreciate the difference and its possible philosophical significance, consider a conception of philosophy that expresses an ongoing desire for a single vision. Taking up the theme of the concluding chapter of Mortal Questions [26], Thomas Nagel declares:

The View from Nowhere is about a single problem: how to combine the perspective of a particular person inside the world with an objective view of that same world, the person and his viewpoint included ([27], p. 3).

What for Rorty is the very thing that stands is the way of moral progress is for Nagel its sine qua non: the search for a philosophical standpoint from which rival ethical claims could be adjudicated; a synoptic metanarrative that would combine the specifically private goods of the individual with the more general goods of society at large, or tell us when a private good should be sacrificed for a public one. For Nagel the desire to transcend oneself in the search for a such unity is a "primary philosophical task of human life-perhaps of any kind of intelligent life” ([27], p. 66) and such self transcendence is the mark not of “a mere... determination to express one's idiosyncratic self” but of reason's mysterious provision of the ability to distance ourselves from the "common opinion and received practices” [28] that in large part determine what in intramundane terms we are.

That idiosyncratic self nevertheless remains the necessary ground for the movement towards transcendence. Consequently, the "the difficulty of reconciling subjective and objective points of view... takes its purest form in a sense of incredulity that one should be anyone in particular" ([26], p. 206). This thought becomes expressed in the form of a question of two halves: "How can NG be me? How can I be NG?” ([27], p. 13). The first part of the question is intended to draw attention to the fact that the centreless conception of the world, one comprising, say, a lading-list of propositions true of it and its inhabitants, appears to leave no room for the ineliminably subjective fact that I am one of them. The second part of the question suggests that my connection with anything as specific as a particular person, a particular set of facts, seems at best contingent. Collectively, these questions bring into focus the ' $\mathrm{I}$ ', the objective self that at the limit is abstracted from any concrete feature of NG. The primary philosophical task Nagel speaks of is thus to develop an account of the centreless conception that would incorporate the first-person truth and thereby harmonise the subjective conception and the objective one: a single vision that would combine for each of us the inner and outer standpoints.

To see how this links up with the question of autobiography, consider an adaptation of a well-known thought-experiment due originally to Castañeda [29] and discussed by Perry [30]. I awake alone, an amnesiac, in a vast library. Perusing its contents, I develop an interest in a certain character, NG, and undertake to write an account of his life. My intention is presumably that of every good biographer: to construct the story of a life that relates reflections on character and subjective states to dealings with others and events in the world in general; that is, to reconcile on some terms the inner and the outer, the private and the public, the subjective and the objective. In the philosophy of mind, the example illustrates the curious logical structure of self-knowledge and served as partial inspiration for reflections like Nagel's: I can know all the facts about me and yet not know that they are about me. If my inquiries give me a substantial account of what NG is, the fact remains that NG is me: that 
centreless conception has to be recognisable to me as me in a way that by hypothesis it cannot be. At the same time, I seem to be more than just NG: the 'I' transcends the specific details of any description.

For Nagel, as we have seen, the account that would harmonise the inner and the outer is intelligible only in terms of a development of that centreless conception. However, I want to suggest that the desire for self-transcendence that the search for a unifying story expresses can also indicate a move in the direction of the existential and idiosyncratic. Before developing this point, consider how the experiment illuminates the difference between self- and auto- biography. What NG produces is self-biography. Self-biography cannot become autobiography by the addition of a new explanatory theory: no version or superposition of, for example, Marxism or Psychoanalysis will enable one to move from an outside view to an inside view. NG has potential access to all these and future theoretical developments, but that does not mean that he thereby knows that the story is his story, with all the implications that represents. Furthermore, there is a sense in which autobiography cannot be convicted of error in the way biography can. As Roy Pascal notes, "even if what they tell us is not factually true ... it always is true evidence of their personality” [31]. One can easily imagine NG, for example, using NG's autobiography as a source for his biography. For the reader, then, the self of the autobiography is always transcendent: any inconsistency demands a hermeneutic twist to realign the horizon of interpretation, but the thought that it is an account of a self remains. Equally, for the autobiographer, the story always has to be my story; the story of an I which it both is and yet an I which in some sense stands as its condition of possibility. For both the inner and the outer accounts, some notional self serves as the source of justification for the knowledge claimed. From this perspective, Nagel's elusive subjective fact that NG is me is captured by the existential recognition that the story is my story. Similarly, the sense that the I is non-identical with NG suggests that if it is a story it has to be a story $I$ tell and recognise as an authentic account of my life-a life understood from the inside and the outside.

With this in mind, let's return to the quote from Nietzsche. The suggestion is that all great philosophy has hitherto been a restricted form of self-biography; the fundamentally moral trace of an irreflexive desire to represent the "order of rank" of one's "innermost drives" in the form of a narrative expressing "the ultimate purpose of existence" ([10], §6). The latter, as we have seen, is precisely how Nagel thinks of his objective project for the unification of the subjective and objective points of view. From Nietzsche's perspective, then, it would seem that the existential spring of philosophy is rendered inauthentic by this compulsion to represent such 'errors' as the 'truth', and this provides him with his narrative standpoint. Just as Hegel appropriated history in the name of the Geist's moment of self-consciousness, Nietzsche can apply to himself what his predecessors could only blindly enact. The reflexive element that distinguishes auto- from self- biography finds its own 'moral intention' in Nietzsche's consuming desire for authenticity: for the construction of a self that evades the call of others, not least that supreme other, the truth of an unchanging Being.

In Section 2 we touched briefly on how Nietzsche's aestheticist desire for authenticity intersects with the 'Modernity Problem', and Rorty's response to it. With the conclusion of that chapter in mind I suggest an alternative to the Nietzschean view; namely, that the autobiographical construction of a life from the standpoint of which one's own public and private goods are judged to be commensurable can be interpreted as the 'real germ of life' of the desire for a standpoint from which a philosophical resolution of the notional incommensurability of goods public and private, high and low, can be 
achieved. In other words, the 'moral intention' behind that philosophical search for a 'single vision' which would assimilate the inner to the outer, the subjective to the objective, can be given content in the philosophical autobiography, just as an autobiography itself (on this model) aims to present an account of the self both in its reflexive structure and its relationship with others and the world.

Let's develop this idea in the context of a specific example: that of the most 'sacred' of Mill's 'sacred texts'. In his Autobiography, Mill assesses his early life as follows:

From the winter of 1821, when I first read Bentham, and especially from the commencement of the Westminster Review, I had what might truly be called an object in life; to be a reformer of the world. My conception of my own happiness was entirely identified with this object.

Five years later, he continues, “I awakened from this as from a dream” ([32], p. 80):

I was in a dull state of nerves, such as everybody is occasionally liable to; unsusceptible to enjoyment or pleasurable excitement; one of those moods when what is pleasure at other times, becomes insipid or indifferent; the state, I should think, in which converts to Methodism usually are, when smitten by their first "conviction of sin." In this frame of mind it occurred to me to put the question directly to myself, "Suppose that all your objects in life were realized; that all the changes in institutions and opinions which you are looking forward to could be completely effected at this very instant: would this be a great joy and happiness to you?" And an irrepressible self-consciousness distinctly answered, “No!” At this my heart sank within me: the whole foundation on which my life was constructed fell down. All my happiness was to have been found in the continual pursuit of this end. The end had ceased to charm, and how could there ever again be any interest in the means? I seemed to have nothing left to live for ([32], p. 81).

This 'crisis' in Mill's 'mental history' leads him to revise his account of the existential significance of one's own happiness in two ways: Firstly, that if you “Ask yourself whether you are happy... you cease to be so. The only chance is to treat, not happiness, but some end external to it, as the purpose of life. Let your self-consciousness, your scrutiny, your self-interrogation, exhaust themselves on that” ([32], p. 86). By way of compensation for this anti-self-consciousness, however, Mill adds:

the other important change which my opinions at this time underwent was that I, for the first time, gave its proper place, among the prime necessities of human well-being, to the internal culture of the individual... I now began to find meaning in the things which I had read or heard about the importance of poetry and art as instruments of human culture ([32], p. 86).

Such insights bring about a revision of the Benthamic principle of utility and as a consequence Utilitarianism expands the concept of pleasure to incorporate an appreciation of man's “elevated faculties” ([33], p. 78). Mill thus finds himself able to detach pleasure, or happiness, from the temporality of satisfaction, or contentment, and to conclude famously that since their higher forms are possessed of an "intrinsic superiority... It is better to be a human being dissatisfied than a pig satisfied; better to be Socrates dissatisfied than a fool satisfied” ([33], p. 79). The judgement that certain goods are intrinsically superior to others in the pursuit of human flourishing is legitimated by the claim that only the party who has experienced both - neither the pig nor the fool-has access to the standpoint from which an assessment of their relative merits can be made. He can thus aver that "the utilitarian standard... is not the agent's own greatest happiness, but the greatest amount of happiness 
altogether” ([33], p. 80): The 'internal culture of the individual' is not thereby regarded as a subjective barrier to an objective account of morality and justice.

On the face of it, Mill's utilitarian standard is a classic exemplification of Rorty's quest for a 'single vision': the search either for a narrative that would synthesise the standpoint of every individual or a criterion with which the competing beliefs and desires of individuals could be assessed. It is the sort of attempt to integrate a private, subjectivist, or individualist component of value into the larger objective or public account that seems destined to reduce all difference to sameness; the kind of aspiration that one finds criticised by those like Nietzsche who sees the process in reverse. For the latter, Mill is a “flathead” ([11], §30) with an “insipid and cowardly concept “man” ” ([11], §340). He continues:

I abhor his vulgarity, which says: "What is right for one is fair for another"... The presupposition here is ignoble in the lowest sense: here an equivalence of value between my actions and yours is presupposed; here the most personal value of an action is simply annulled ([11], §926).

This is, as it were, grist to the mill (!) for critics of utilitarianism for whom the demands of such an impersonal morality are at best an impediment to the leading of a Good Life and at worst a disciplinary mechanism of repression. And one might indeed consider that it was fortunate for Mill that although he came to realise that the fulfilment of the social and political goals that had hitherto given his life its purpose would not lead to personal happiness, the source of his private epiphanies - the aesthetic bliss that would add the necessary subjective dimension to his own flourishing-was not a Byronic nihilism that might have lured him towards a disengaged aestheticism, but Wordsworth's affirmative lyricism:

I needed to be made to feel that there was real, permanent happiness in tranquil contemplation. Wordsworth taught me this, not only without turning away from, but with a greatly increased interest in, the common feelings and common destiny of human beings ([32], p. 89).

Mill's fortune is not, however, the point. What is, is that Mill's autobiography involves the construction of a life from the standpoint of which his own public and private goods were judged to be commensurable. Had Nietzsche read it he might have been more willing to see Mill's philosophical project as a principled attempt to render himself authentic to his own perceived dualistic needs-to harmonise the private desires upon which his happiness ultimately appeared to rest and which constituted his uniqueness, with his public commitments. If we relate Mill's 'utilitarian standard' to this harmonisation, it might no longer seem as vacuous as it sometimes does-as vacuous, that is, as he in turn accused Kant's categorical imperative of being ([33], p. 106). Nor might it appear to annul 'the most personal value of an action' since the act of integrating public and private goals could be described as the most personal value of any act. In all likelihood, however, Nietzsche would still have despised the fact that Mill's harmonisation takes place in such a fashion that it re-affirms 'the common feelings and common destiny of human beings,' for that common destiny represented, for Nietzsche, the decadent levelling of an 'insipid and cowardly concept'. Nietzsche believed his task was to authenticate himself through an affirmation of the very values that marked him out as an individual. Had he met his Harriet Taylor, or ever, as Mill describes himself at 20, "loved any one sufficiently to make confiding my grief's a necessity,” he might not "have been in the condition” he was ([32], p. 81). Unlike Mill, however, Nietzsche did not feel that his was "not an interesting, or in any was respectable distress” ([32], p. 81). His sickness and solitude thus find their 'destiny’ in the ironic cadences of Ecce 
Homo - so wise, so clever, such good books - and not in Zarathustra. That, after all, concludes with the pitifully inauthentic sight of its eponymous hero leaving his cave "glowing and strong, like a morning sun emerging from behind dark mountains” ([13], p. 336), having finally overcome his 'higher men', and as a result now strong enough to overcome his pity for the herd and thus dwell amongst them once more in the market place.

The harmonisation of Mill's private and public desires finds expression in the philosophical principle of the 'utilitarian standard'; but only insofar as it is given manifest content by his 'life'. Similarly, Nietzsche's failure to overcome the conflict between his pity for others and the feeling that such pity was a sickness of inauthenticity finds expression in his philosophy and his 'life'. The 'success' of Mill's life mirrors the 'failure' of his Philosophy as a universal, for the only content that can be given to the 'utilitarian standard' is the successful harmonisation in a life of private and public goods: as a foundational principle it can provide no guide as there is no objective assessment of how goods should be valued that is wholly independent of particular valuers. Any imposition of values would necessarily be seen as impoverishing the concept of an authentic life by prescribing in advance the range of goods from which it could be constructed. Nietzsche's ironic, philosophical perspectivalism dramatises both the impossibility and the undesirability of a Philosophical reconciliation of private and public goods, whilst demonstrating at the same time that the desire for such authenticity can have unfortunate consequences not only for others, but for one's life.

\section{No Single Vision}

Section 2 concluded that Rorty's project for identifying the post-Philosophical intellectual is consistent only if one associates liberal ironism with the sort of self-transformative achievement undergone by the ancient Sceptic when she 'overcomes' in herself the Dogmatism that initially motivated her intellectual quest. In this respect, Rorty is the liberal ironist, not the theorist of liberal irony. In Section 3 I suggested that philosophical autobiography can be interpreted in such a way that it expresses the inappropriateness of Philosophy for the task of presenting a unifying narrative that legitimates both one's public and private aspirations_one's desire to legitimate the resources for one's 'internal culture' oneself and to simultaneously honour one's commitments to others. I'll conclude by briefly arguing that this is exemplified in a piece Richard Rorty wrote in 1992, entitled 'Trotsky and the Wild Orchids ${ }^{, 12}$. In an appropriately Rortian appropriative mode, this can be read as a self-conscious attempt to use the genre to offer an account that evinces the humility of a Mill and the irony of a Nietzsche. It presents the importance to oneself of one's project for personal happiness or authenticity whilst showing that it is unnecessary to legitimate this by adverting to a Philosophical standpoint from which it is rendered commensurable with one's obligations in the public realm and that it is politically unwise to use one's individualistic, existential strivings for authenticity as a guide to how to treat others. It is an attempt to see with Mill that one's political projects might be fulfilled and one not be happy whilst seeing with Nietzsche that this need not lead one to conclude that one need, can, or indeed, ought to find a Philosophical principle that somehow combines the two perspectives and thence legitimate both. Moreover, it does this by dramatising how the failure to find a Philosophical

12 On the original typescript this was called 'No Single Vision'. Rorty’s model here is [34]. 
reconciliation of the two, itself an expression of the 'anxiety of influence', is the only general legitimation of the idea of a single vision available.

'Trotsky and the Wild Orchids', then, is the story of how a "clever, snotty, nerdy only child” ([3], p. 3) who had an adolescent passion for the wild orchids of New Jersey sought to combine this "private, snobbish, incommunicable interests" ([3], p. 7) with the belief, inherited from his parents, that "the point of being human was to spend one's life fighting social injustice” ([3], p. 6). The 'single vision' against which the piece ultimately speaks is the one that would "hold reality and justice" ([3], p. 7) together; reality being "the Wordsworthian moments in which, in the woods around Flatbookville... I had the felt touched by something numinous, something of ineffable importance,” and justice being "what Norman Thomas and Trotsky both stood for, the liberation of the weak from the strong." He wanted, he adds, to be "both an intellectual and spiritual snob and a friend of humanity - a nerdy recluse and a fighter for justice" ([3], pp. 7-8). Lacking "the humility which Christianity demanded, and of which," he continues, "I was apparently incapable” ([3], p. 9) philosophy appears the best way in which to combine the contemplative life towards which the orchids gestured with the

ability to convince bullies that they should not beat one up, the ability to convince rich capitalists that they must cede their power to a cooperative, egalitarian, commonwealth ([3], p. 10).

Unlike Mill, whose own 'Wordsworthian moments' cathected his universal 'utilitarian standard', the narrator comes to embrace a more Nietzschean affirmation of human finitude whilst attempting to dissociate it from the fantasy of an escape from the marketplace where the coin of 'the common feelings and common destiny of human beings' is redeemed:

one should try to abjure the temptation to tie in one's moral responsibilities to other people with one's relation to whatever idiosyncratic things or persons one loves with all one's heart and soul and mind ([3], p. 13).

To forswear such a temptation, then, is to renounce the standpoint of the 'single vision' that philosophy dreams of. Above all, that signifies the renunciation of the belief that any heir to, or ancestor of, Mill's 'standard' will be found that will combine reality and justice and thereby serve the purpose of determining in advance, and universally, when idiosyncrasies as yet undreamed of should end, and responsibilities as yet unimagined should begin. No philosophical account of rationality, or concept of experience, reality or truth will allow us to legitimate our norms and adjudicate with respect to competing claims.

The apotheosis of the search for a 'single vision', then, comes with the realisation that "the whole idea of holding reality and justice in a single vision had been a mistake - that the pursuit of such a vision had been precisely what led Plato astray" ([3], p. 12); that the narrator's own "hope of getting a single vision by becoming a philosopher had been a self-deceptive atheist's way out” ([3], p. 13), a sort of sublimation of the religious desire for a "surrogate parent who, unlike any real parent, embodied love, power and justice in equal measure” ([3], p. 12). This association of Philosophy's authority with that of a quasi-parental deity is a variant on a familiar theme; as is the idea that Philosophical thinking is misleading or deceiving. As we've already seen, attempts to unconceal that deception by making it part of a narrative of how others were misled rely on revealing the sources of the deception within a true account of how things really are. This retains for the discipline its traditional authority (and risks reproach for a deeper self-deception). 
One might of course liberate oneself from the authority Philosophy has over one's own intellectual projects and in doing so feel no compulsion to communicate the nature of that escape because such an impulse is itself an expression of continuing 'control' by Philosophy. However, this does nothing to free others from such an authority, and the narrator did not choose that path; perhaps because, although the tranquility it would bring might recollect the orchidaceous, it would bring no peace to those feelings inspired by his own parents. It would seem that if he is to remain loyal to the 'moral (or immoral!) intentions' of his youth the narrator must free not only himself from the authority of Philosophy but others also. Ultimately, then, 'worries about what, if anything, philosophy is good for' are settled by the recognition that its 'end' is to help bring about its own demise in a way that frees others from the idea that there is an authority (philosophy, God) that transcends the merely human. The task is to unfetter the authority invested in something other, and make it available to renew the sense of our own control over our own (human) destiny.

It is in this sense that, as Habermas notes, Rorty "attributes a culturally critical significance to his anti-Platonic turn, a significance that is supposed to extend far beyond his own person and his private switch of philosophical allegiance" ([35], p. 32). It is only on the assumption that Western culture is constrained by an immature desire for a quasi-parental authority that Rorty's own rejection of such-in the form of Philosophy — could have greater significance. And it is only by simultaneously offering a diagnosis of that immaturity, and a vision of what human beings might be like without it, that the renewal of the Enlightenment's promise of freedom can be given shape as a task for us.

The account of Rorty's intellectual progress ends with the publication of Contingency, Irony and Solidarity. It constitutes the fullest expression of how a dominant conception of Philosophy's task is exhausted in and through the recognition that the desire for a single vision is deceptive, and aims to give intellectuals a narrative of self-understanding that is free of such deception. It is written from the perspective that the autobiographical fragment reveals as the one its author achieved at the point when the controlling deception was unmasked, which in turn allowed the "narrative of maturation" ([35], p. 31) to be written. Despite its theme (and original title), it is an account of the construction of a single vision. Just as for Mill the harmonisation of public and private in the Autobiography surpassed the merely abstract unity of the utilitarian standard, Rorty's piece is a meta-description of how the failure to find a single vision (including a theory of post-Philosophical intellectual self-understanding) can itself be surpassed in the single vision that is an account of one's life. To share the standpoint of the narrator is to see that it is possible both to reject both the idea of the Philosophical quest for a single vision and, in so doing, as “a single person” ([2], p. 198) combine in one's life the elements that comprise it ${ }^{13}$.

13 I have omitted from this paper discussion of Rorty’s relationship to Wittgenstein. In part this is because some of the 'work on self' idea of therapy is found in the approach of the Sceptics; in part it is because I say something about Rorty's characterisation of Wittgenstein in ([8], ch. 4). Rorty's official position is that as an edifying philosopher Wittgenstein's work is 'merely' reactive, serving no purpose in the post-Philosophical culture ([36], p. 369). It might of course be argued that Rorty's relationship to philosophy is controlled by an all-too Nietzschean desire to evade the influence of Wittgenstein (the highest of his 'higher men'), evidenced by his failure to take "the intellectual obligations of traditional philosophy” sufficiently seriously [37]. Such an approach would include discussion of Cavell-inspired readings of Wittgenstein like Conant's and those collected in [38]. For Conant's criticism of Rorty see [39,40]. 


\section{Acknowledgments}

Earlier versions of this paper were given at the Universities of Aberystwyth and Anglia Ruskin. My thanks to the anonymous referees for very helpful suggestions.

\section{Conflict of Interest}

The author declares no conflict of interest.

\section{References}

1. Mark Lilla. “Isaiah Berlin Against the Current.” The New York Review of Books 60, 7 (2013): 40-42.

2. Richard Rorty. Contingency, Irony, and Solidarity. Cambridge: Cambridge University Press, 1989.

3. Richard Rorty. "Trotsky and the Wild Orchids." In Philosophy and Social Hope. London: Penguin, 1999, 3-20.

4. Jens Brockmeier, and Donal A. Carbaugh, eds. Narrative and Identity: Studies in Autobiography, Self, and Culture. Amsterdam: John Benjamins Publishing Co., 2001.

5. Qi Wang. The Autobiographical Self in Time and Culture. Oxford: Oxford University Press, 2013.

6. Neil Gascoigne. Scepticism. Montreal: McGill-Queen’s University Press, 2003.

7. Richard Rorty, ed. The Linguistic Turn. Chicago: Chicago University Press, 1967.

8. Neil Gascoigne. Richard Rorty: Liberalism, Irony and the Ends of Philosophy. Cambridge: Polity Press, 2008.

9. David R. Hiley. Philosophy in Question: Essays on a Pyrrhonian Theme. Chicago: Chicago University Press, 1988.

10. Friedrich Nietzsche. Beyond Good and Evil. Translated by Judith Norman. Cambridge: Cambridge University Press, 2002.

11. Friedrich Nietzsche. The Will to Power. Translated by Walter Kaufmann, and R.J. Hollingdale. New York: Vintage Books, 1968.

12. Friedrich Nietzsche. Ecce Homo. Translated by Walter Kauffman. New York: Vintage Books, 1969.

13. Friedrich Nietzsche. Thus Spake Zarathustra. Translated by R.J. Hollingdale. London: Penguin, 1961.

14. Jürgen Habermas. The Philosophical Discourse of Modernity. Translated by F.G. Lawrence. Cambridge: MIT Press, 1990.

15. Robert B. Pippin. Modernism as a Philosophical Problem, 2nd ed. Oxford: Blackwell, 1999.

16. Jeffrey Stout. “On Our Interest in Getting Things Right.” In New Pragmatists. Edited by Cheryl Misak. Oxford: Clarendon Press, 2007.

17. Richard Rorty. The Consequences of Pragmatism. Minneapolis: Minnesota University Press, 1982.

18. Richard Rorty. Truth and Progress: Philosophical Papers, Volume 3. Cambridge: Cambridge University Press, 1998.

19. Richard Rorty. “Is Derrida a Transcendental Philosopher?” In Essays on Heidegger and Others: Philosophical Papers, Volume 2. Cambridge: Cambridge University Press, 1991, 119-28. 
20. Sextus Empiricus. Outlines of Scepticism. Translated by Julia Annas, and Jonathan Barnes. Cambridge: Cambridge University Press, 1994.

21. Myles F. Burnyeat, and Michael Frede, eds. The Sceptics: An Original Controversy. Indianapolis: Hackett, 1998.

22. John Rawls. “Kantian Constructivism.” The Journal of Philosophy 77 (1980): 519.

23. Richard Rorty. "Religion in the Public Square: A Reconsideration." The Journal of Religious Ethics 31 (2003): 142, 144.

24. Richard Rorty. "Religion as Conversation-Stopper.” Common Knowledge 3 (1994): 1-6.

25. Richard Rorty. "Incorrigibility as the Mark of the Mental.” The Journal of Philosophy 67 (1970): 406, fn. 11.

26. Thomas Nagel. Mortal Questions. Cambridge: Cambridge University Press, 1979.

27. Thomas Nagel. The View from Nowhere. Oxford: Oxford University Press, 1989.

28. Thomas Nagel. The Last Word. Oxford: Oxford University Press, 1997, 3.

29. Hector-Neri Castañeda. “'He’: A Study in the Logic of Self-Consciousness.” Ratio 8 (1966): 130-57.

30. John Perry. "“Borges and I' and 'I'." The Amherst Lecture in Philosophy 2 (2007), 1-16. http://www.amherstlecture.org/perry2007/.

31. Roy Pascal. Design and Truth in Autobiography. London: Routledge, 1960, 1.

32. John Stuart Mill. Autobiography. Oxford: Oxford University Press, 1971.

33. John Stuart Mill. On Liberty and Other Essays. Oxford: Oxford University Press, 1991.

34. John Dewey. "From Absolutism to Experimentalism." In The Later Works, 1925-1953. Carbondale and Edwardsville: Southern Illinois Press, 1984, vol. 5, 147-60.

35. Jürgen Habermas. "Richard Rorty’s Pragmatic Turn.” In Rorty and His Critics. Edited by Robert Brandom. Oxford: Blackwell, 2000: 31-55.

36. Richard Rorty. Philosophy and the Mirror of Nature. Princeton: Princeton University Press, 1979.

37. John McDowell. Mind and World. Cambridge: Harvard University Press, 1994, 146.

38. John Gibson, and Wolfgang Huemer, eds. The Literary Wittgenstein. London: Routledge, 2004.

39. James Conant. "Freedom, Cruelty and Truth: Rorty versus Orwell.” In Richard Rorty and His Critics. Edited by Robert Brandom. Oxford: Blackwell, 2000, 268-342.

40. James Conant. "Rorty and Orwell on Truth.” In On Nineteen Eighty-Four: Orwell and the Future. Edited by Abbot Gleason, Jack Goldsmith, and Martha Nussbaum. Princeton: Princeton University Press, 2005.

(C) 2013 by the author; licensee MDPI, Basel, Switzerland. This article is an open access article distributed under the terms and conditions of the Creative Commons Attribution license (http://creativecommons.org/licenses/by/3.0/). 